\title{
Article \\ Efficient Production of Naringin Acetate with Different Acyl Donors via Enzymatic Transesterification by Lipases
}

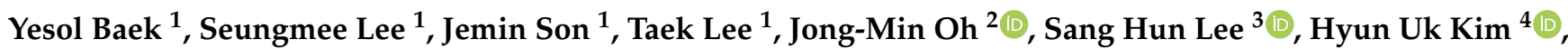 \\ Sang Woo Seo ${ }^{5}$, , Si Jae Park ${ }^{6, *}$, Hah Young Yoo ${ }^{1,7, * \mathbb{C}}$ and Chulhwan Park ${ }^{1, *(1)}$
}

Citation: Baek, Y.; Lee, S.; Son, J.; Lee, T.; Oh, J.-M.; Lee, S.H.; Kim, H.U.; Seo, S.W.; Park, S.J.; Yoo, H.Y.; et al. Efficient Production of Naringin Acetate with Different Acyl Donors via Enzymatic Transesterification by Lipases. Int. J. Environ. Res. Public Health 2022, 19, 2972. https:// doi.org/10.3390/ijerph19052972

Academic Editors: Paul B.

Tchounwou, Kamal Dua, Murtaza M. Tambuwala and Keshav Raj Paudel

Received: 20 December 2021

Accepted: 30 January 2022

Published: 3 March 2022

Publisher's Note: MDPI stays neutral with regard to jurisdictional claims in published maps and institutional affiliations.

Copyright: (C) 2022 by the authors. Licensee MDPI, Basel, Switzerland. This article is an open access article distributed under the terms and conditions of the Creative Commons Attribution (CC BY) license (https:// creativecommons.org/licenses/by/ $4.0 /)$.
1 Department of Chemical Engineering, Kwangwoon University, Seoul 01897, Korea; isss9511@naver.com (Y.B.); 981sm@naver.com (S.L.); wkqh14@gmail.com (J.S.); tlee@kw.ac.kr (T.L.)

2 Department of Electronic Materials Engineering, Kwangwoon University, Seoul 01897, Korea; jmoh@kw.ac.kr

3 Department of Chemical and Biological Engineering, Hanbat National University, Daejeon 34158, Korea; sanghunlee@hanbat.ac.kr

4 Department of Chemical and Biomolecular Engineering, Korea Advanced Institute of Science and Technology (KAIST), Daejeon 34141, Korea; ehukim@kaist.ac.kr

5 School of Chemical and Biological Engineering, Institute of Chemical Process, Seoul National University, Seoul 08826, Korea; swseo@snu.ac.kr

6 Division of Chemical Engineering and Materials Science, Ewha Womans University, Seoul 03760, Korea

7 Department of Biotechnology, Sangmyung University, Seoul 03016, Korea

* Correspondence: parksj93@ewha.ac.kr (S.J.P.); y2h2000@smu.ac.kr (H.Y.Y.); chpark@kw.ac.kr (C.P.)

\begin{abstract}
Naringin, one of the citrus flavonoids and known as a natural antioxidant, has limited bioavailability owing to its low stability and solubility. However, naringin esters formed via acylation have recently been reported to possess improved physical and chemical properties. The development of these compounds has a great potential in the food, cosmetic and pharmaceutical industries, but low conversion and productivity are barriers to industrial applications. This study aimed to improve the conversion of naringin acetate, which is formed via the enzymatic reaction between naringin and an acyl donor. An optimal reaction condition was determined by evaluating the effect of various variables (enzyme type, enzyme concentration, acyl donor, molar ratio of reactants, reaction temperature, and solvent) on the synthesis of naringin acetate. The optimal condition was as follows: $3 \mathrm{~g} / \mathrm{L}$ of Lipozyme TL IM, molar ratio of 1:5 (naringin:acyl donor), reaction temperature of $40{ }^{\circ} \mathrm{C}$, and acetonitrile as the reaction solvent. Under this condition, the maximum conversion to naringin acetate from acetic anhydride and vinyl acetate was achieved at approximately $98.5 \%(8 \mathrm{~h})$ and $97.5 \%$ (24 h), respectively. Compared to the previously reported values, a high conversion was achieved within a short time, confirming the commercial potential of the process.
\end{abstract}

Keywords: antioxidant; flavonoid; naringin; flavonoid ester; flavonoid acetate; acylation; lipase; transesterification; enzymatic synthesis

\section{Introduction}

Flavonoids are naturally occurring antioxidants with more than 8000 types identified to date. Based on their structure, they are classified as flavones, flavonols, flavanones, flavanonols, isoflavones, and anthocyanins. Flavonoids are generally found in fruits, vegetables, flowers, and tea [1], and are widely regarded as preventative and therapeutic agents for chronic diseases owing to their biological and pharmacological activities [2,3]. Naringin is a glycosylated flavonoid with rhamnose and glucose attached to the C-7 position of naringenin, an aglycone form. Naringin, a typical citrus flavonoid widely found in grapefruits and citrus peels [4], exerts pharmacological effects, including strong antioxidant [5], antibacterial [6], and anticancer [7] properties, as well as blood and cholesterol-lowering effects [8]. Naringin has advantages over aglycone flavonoids, which are limited in application owing to their mutagenic and cytotoxic properties [9]. Indeed, several studies 
have reported naringin supplementation as a suitable treatment for obesity, diabetes, hypertension, and metabolic syndrome [4]. Meanwhile, the Citrus genus is one of the most important genera worldwide, with a global distribution of up to 90 million tons per year resulting in a significant production of citrus peel waste [10]. However, due to their high flavonoid content, increasing attention has been directed to improving their application in various industries.

Glycosylated flavonoids are generally limited in their bioavailability, owing to their low solubility and stability in hydrophobic environments. These limitations hinder their application from in vitro to in vivo systems [11]. The antioxidant effect and radical scavenging ability of flavonoids depend on their chemical structure as well as their lipophilicity [12] In addition, glycosylated flavonoids are unstable due to the presence of many hydroxyl groups and are, thus, readily decomposed by light, oxygen, and high temperatures [2]. It is therefore necessary to improve the solubility of naringin in the lipid phase to increase its absorption and stability in physiological conditions. Acylation may be a strategy to increase the solubility of naringin. As chemical acylation is performed at high temperature or high pressure, it is difficult to esterify unstable substances, such as polyols, by this method. In addition, protection and deprotection steps are required to perform the regioselective acylation of flavonoids like polyol [13]. Considering that these processes often generate toxic by-products and require harsh reaction conditions, including high temperatures [14], the application of chemical methods in food has remained limited owing to the adverse effects on the environment and overall safety concerns. In contrast, enzymatic methods use mild conditions and one-step synthesis reactions, without the need for protection and deprotection steps. Moreover, it is an eco-friendly synthesis method, as it generates less by-products due to its excellent regioselectivity [14-16].

Esters, such as triacylglyceride (TAG), phospholipid derivatives of phenolic acids, and flavonoid esters, can be produced by enzymatic methods [17,18]. The enzymatic acylation of flavonoids has been studied using proteases, esterases, acyltransferases, and lipases [14,19]. Currently, lipases are used in most flavonoid ester synthesis studies. Lipase is a well-known enzyme with potential in biological processes owing to its availability and stability in both organic and aqueous phases. In particular, microbial lipase is stable in organic solvents, does not require cofactors, and has broad specificity. Therefore, it has been applied to various industries based on the findings of many studies on its reaction mechanism and structure [15,20-22].

There are several drawbacks associated with enzymatic synthesis. Besides being expensive, enzymes are proteins and, therefore, prone to denaturation in response to environmental conditions; moreover, their separation and purification are difficult [20-23]. Immobilization may overcome these shortcomings of free enzymes. When an immobilized enzyme is used, it can be readily separated and reused, thus reducing the overall consumption of the enzyme. Further, the stability against heat and organic solvents is increased $[14,15,24]$, as a result of which many recent studies on the synthesis of flavonoid esters have been conducted using immobilized lipases [20,21]. Existing studies on flavonoid ester, including those on naringin acetate, focus on synthesis using enzymatic methods (Table 1). Synthesis via esterification requires a long reaction time, and the conversion is relatively low. Meanwhile, in transesterification synthesis, the reaction is conducted using either a high molar ratio of the reactants or a large amount of enzyme. A previous study reported the synthesis and statistical optimization of flavonoid acylation using esculin and linseed oil [25], the results of which showed that a conversion of $78.5 \%$ could be obtained after $96 \mathrm{~h}$ of reaction time. In the case of naringin acetate, a study reported a conversion of $41.03 \%$ after $96 \mathrm{~h}$ of reaction between naringin and vinyl acetate [10]. 
Table 1. Summary of naringin ester conversion by enzymatic reaction.

\begin{tabular}{|c|c|c|c|c|c|}
\hline \multicolumn{2}{|c|}{ Reactant } & \multirow{2}{*}{$\begin{array}{c}\text { Reaction Type } \\
\text { Esterification }\end{array}$} & \multirow{2}{*}{$\frac{\text { Reaction Time }}{48 \mathrm{~h}}$} & \multirow{2}{*}{$\begin{array}{c}\text { Conversion } \\
93.10 \%\end{array}$} & \multirow{2}{*}{$\begin{array}{l}\text { Ref. } \\
{[14]}\end{array}$} \\
\hline Naringin & Oleic acid & & & & \\
\hline \multirow[t]{3}{*}{ Naringin } & Coconut oil & Esterification & $90 \mathrm{~h}$ & $75.43 \%$ & [25] \\
\hline & Linseed oil & & & $76.70 \%$ & \\
\hline & Sunflower oil & & & $85.08 \%$ & \\
\hline Naringin & Ricinoleic acid & Esterification & $120 \mathrm{~h}$ & $33 \%$ & [26] \\
\hline \multirow[t]{3}{*}{ Naringin } & Oleic acid & Esterification & $96 \mathrm{~h}$ & $78.4 \%$ & [27] \\
\hline & Linoleic acid & & & $77.6 \%$ & \\
\hline & Linolenic acid & & & $86.6 \%$ & \\
\hline \multirow[t]{3}{*}{ Naringin } & Oleic acid & Esterification & $96 \mathrm{~h}$ & $80-90 \%$ & [28] \\
\hline & Lauric acid & & & & \\
\hline & Linolenic acid & & & & \\
\hline \multirow[t]{2}{*}{ Naringin } & Vinyl acetate & Trans-esterification & $96 \mathrm{~h}$ & $41.03 \%$ & [10] \\
\hline & Vinyl octanoate & & & $91.40 \%$ & \\
\hline Naringin & Vinyl butyrate & Trans-esterification & $144 \mathrm{~h}$ & $90 \%$ & [12] \\
\hline Naringin & Vinyl laurate & Trans-esterification & $8 \mathrm{~h}$ & $50 \%$ & [29] \\
\hline
\end{tabular}

Many reports have suggested that acylated flavonoids have improved physical and chemical properties, such as thermal stability, light resistance, and lipophilic solubility [14,30-35]. The improved function of acylated flavonoids increases its applicability in various industries, including food, pharmaceutical, and cosmetics. Foods containing flavonoids have a bitter and astringent taste; however, acylated flavonoids have a more favorable taste, that can be applied to food or cosmetics such as toothpaste [30]. In the pharmaceutical industry, acylated flavonoids have been found to be effective in preventing or treating diseases related to hyperglycemia, such as hyperlipidemia and stroke [31]. Additionally, flavonoids acylated with polyunsaturated fatty acids reduce the vascular endothelial growth factor (VEGF) of K562 human leukemia cells and, thus, may represent effective anti-tumor agents [32]. Moreover, Hattori et al. synthesized naringin ester using Lipozyme RM IM and investigated its anti-inflammatory effects [33]. They found that naringin ester exhibited superior anti-inflammatory properties compared to naringin. In addition, flavonoid esters exerted better skin protection properties, protecting against UV-radiation-induced mitochondrial or nuclear DNA damage, compared to flavonoids. As such, they have been reported to protect the skin and scalp from aging and inflammation [34]. Among the various acyl donors, short chains such as an acetyl group were found to improve transport through the aqueous environment, along with its interaction or penetration through phospholipid membranes [35].

Li et al. synthesized naringin ester, including naringin acetate, using whole cells and confirmed its antioxidant effect [10]. Their results confirmed that naringin acetate has a higher free radical scavenging capacity for 2,2-diphenyl-1-picrylhydrazyl (DPPH) and 2,2'-azino-bis (3-ethylbenzothiazoline-6-sulfonic acid) (ABTS) than naringin. In addition, naringin acetate was found to be more effective than vitamin $\mathrm{E}$, as per an oxygen radical absorbance capacity (ORAC) analysis.

To the best of our knowledge, despite many studies on the synthesis of naringin acetate, few have examined the enzymatic synthesis of naringin acetate for high conversion through the optimization approach. Therefore, to improve the conversion and reaction time in the enzymatic synthesis of naringin acetate, we aimed to identify the optimal synthesis conditions by investigating the effects of different types of lipases, concentrations of lipases, types of acyl donors, molar ratio of reactants, reaction temperature, and solvents. 


\section{Materials and Methods}

\subsection{Materials}

Naringin was purchased from Sigma-Aldrich (St. Louis, MO, USA). Acetic acid, acetic anhydride, methyl acetate, vinyl acetate, propyl acetate, butyl acetate, acetone, tert-butyl alcohol, tert-amyl alcohol, and 1,2-dichloroethane were purchased from DaeJung (Gyeonggi-do, Korea). Ethyl acetate, acetonitrile, and tetrahydrofuran (THF) were purchased from Junsei (Tokyo, Japan). For the immobilized enzyme, commercially used Novozym 435 (Candida antarctica lipase B immobilized on acrylic resin), Lipozyme TL IM (Thermomyces lanuginosus immobilized on a silica gel carrier), and Lipozyme RM IM (Rhizomucor miehei immobilized on a resin carrier) were selected, purchased from Novozymes (Bagsværd, Demark).

\subsection{Enzymatic Synthesis of Naringin Acetate}

Naringin acetate was synthesized through an enzymatic reaction (Figure 1). Before the reaction, the organic solvent was dried for more than one week using $3-\AA$ molecular sieves $(150 \mathrm{~g} / \mathrm{L})$. Naringin was dried for over one week in desiccators with silica gel. Naringin $(10 \mathrm{mM})$ and the acyl donor $(10-110 \mathrm{mM})$, dissolved in an organic solvent, were added to a $50 \mathrm{~mL}$ serum bottle in a $20 \mathrm{~mL}$ working volume. A certain amount of enzyme $(1-9 \mathrm{~g} / \mathrm{L})$ was then added. The serum bottle was sealed to prevent the evaporation of the organic solvent, and the mixture was allowed to react in a shaking incubator at $180 \mathrm{rpm}$ for $48 \mathrm{~h}$.

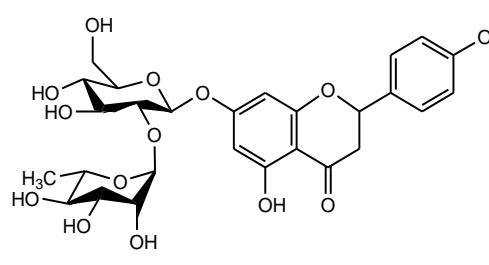

Naringin $\mathrm{C}_{27} \mathrm{H}_{32} \mathrm{O}_{14}$

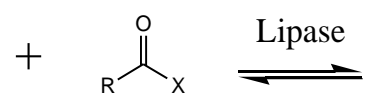

Acyl donor

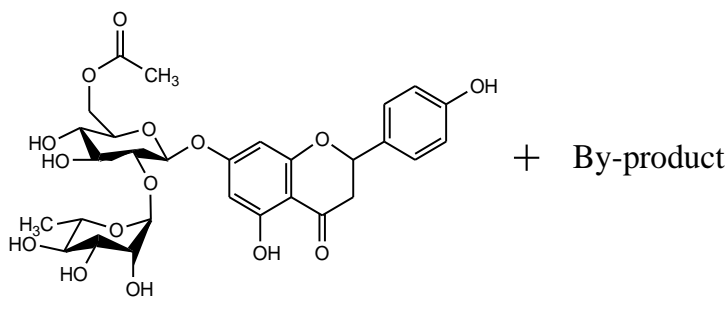

Naringin acetate $\mathrm{C}_{29} \mathrm{H}_{34} \mathrm{O}_{15}$

Figure 1. Reaction formula for the production of naringin acetate from naringin and acyl donors.

\subsection{Optimization of Reaction Conditions}

Optimization was performed using the one factor at a time (OFAT) method, in which only one variable is manipulated at a time, keeping the rest fixed, and optimizing step by step. The effects of six reaction parameters (type of immobilized enzyme, concentration of enzyme, type of acyl donor, molar ratio of reactants, reaction temperature, and solvent) on the synthesis of naringin acetate were investigated (Figure 2). As the basic reaction condition, $5 \mathrm{~g} / \mathrm{L}$ of the enzyme, vinyl acetate as the acyl donor, 1:1 molar ratio of reactants, reaction temperature of $40^{\circ} \mathrm{C}$, and tert-amyl alcohol as the solvent were used. The reaction was conducted in a shaking incubator at $180 \mathrm{rpm}$ for $48 \mathrm{~h}$. Starting with these basic conditions, the factors selected in each stage were applied to the next stage.

To confirm the effect of the immobilized enzyme type on conversion, three types of immobilized lipases (Novozym 435, Lipozyme TL IM, and Lipozyme RM IM) were screened. At this time, the conditions were basic reaction conditions. Thereafter, the enzyme concentration (Lipozyme TL IM) was varied between 1 and $9 \mathrm{~g} / \mathrm{L}$. In acyl donor selection, $3 \mathrm{~g} / \mathrm{L}$ of Lipozyme TL IM was used to screen for acetic acid, acetic anhydride, methyl acetate, vinyl acetate, ethyl acetate, propyl acetate, and butyl acetate. The molar ratio of the reactants was investigated in the range of 1:1 to 1:11 with vinyl acetate or acetic anhydride as the acyl donor. The reaction's temperature was investigated over the range $30-60{ }^{\circ} \mathrm{C}$, and the molar ratio of the reactants was $1: 5$. Finally, various organic solvents (acetonitrile, 1,4-dioxane, acetone, THF, tert-butyl alcohol, tert-amyl alcohol, and 1,2-dichloroethane) were evaluated. 

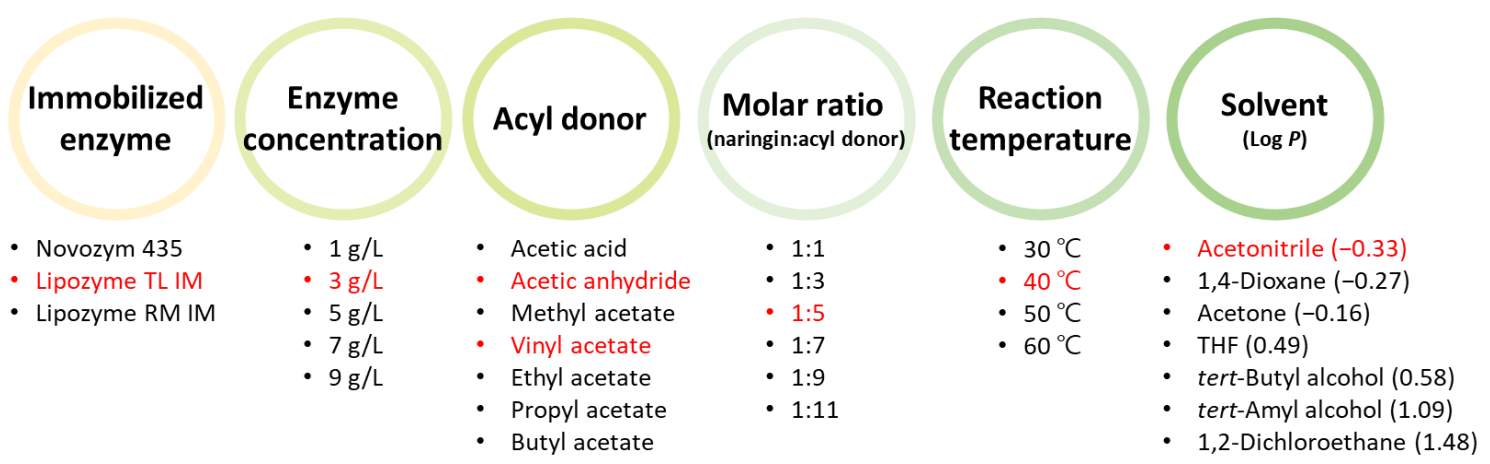

Figure 2. Optimization procedure to produce naringin acetate using naringin and acyl donors. (Red highlighted points: determined variables for the synthesis of naringin acetate).

\subsection{Analytical Methods}

High performance liquid chromatography (HPLC) was used for the quantitative analysis, and performed using Agilent 1260 infinity II (Agilent, CA, USA). After completion of the reaction, a sample was collected using a $1 \mathrm{~mL}$ syringe. The collected solution was 10-fold diluted with methanol, and the enzyme and residue were removed using a syringe filter, and finally injected into a $2 \mathrm{~mL}$ vial. The column used for this analysis was the INNO Column C18 $(120 \AA, 5 \mu \mathrm{m}, 4.6 \times 250 \mathrm{~mm})$. The injection volume was $5 \mu \mathrm{L}$, and the column temperature was maintained at $50{ }^{\circ} \mathrm{C}$. As mobile phases, $3 \%$ acetic acid in water (A) and $100 \%$ methanol (B) were used. The flow rate was $1 \mathrm{~mL} / \mathrm{min}$, and the gradient was as follows: (A/B) 0 min-70/30, $5 \mathrm{~min}-0 / 100,10 \mathrm{~min}-0 / 100,15 \mathrm{~min}-70 / 30$, and $20 \mathrm{~min}-70 / 30$. The analysis was performed at $280 \mathrm{~nm}$ using an UV detector. The conversion was calculated from the initial naringin concentration and the synthesized naringin acetate concentration, as demonstrated in Equation (1) [12,36-38]. The naringin calibration curve was obtained using methanol. Error bars and error ranges represented the standard deviations $(n=2)$.

$$
\text { Conversion }(\%)=\frac{\text { Naringin acetate concentration }}{\text { Initial naringin concentration }} \times 100(\%)
$$

Liquid chromatography-mass spectrometry (LC-MS) was used for the qualitative analysis, and was performed using Agilent 1260 Infinity II and Infinity Lab LC/MSD (Agilent, CA, USA). The solution collected for analysis was 100-fold diluted with methanol, filtered, and injected into a $2 \mathrm{~mL}$ vial. The injection volume, column, and column temperature were the same as in the HPLC analysis method. The mobile phase contained $0.1 \%$ formic acid in water $(\mathrm{A})$ and $0.1 \%$ formic acid in acetonitrile $(\mathrm{B})$. The flow rate was $1 \mathrm{~mL} / \mathrm{min}$, and the gradient was as follows: (A/B) 0 min-70/30, 5 min-0/100, 10 min-0/100, 15 min-70/30, and $20 \mathrm{~min}-70 / 30$. The presence of naringin was confirmed by the SIM mode $(\mathrm{m} / z 603.20)$, and that of naringin acetate was confirmed by the SCAN mode. The mass spectrum was scanned in the $600-700 \mathrm{~m} / \mathrm{z}$ range.

\section{Results and Discussion}

\subsection{Synthesis of Naringin Acetate by Transesterification with Acyl Donors}

In this study, naringin acetate was synthesized by the acylation of naringin in an organic solvent. A quantitative analysis of the synthesized naringin acetate was performed by HPLC. Most of the studies to date have reported naringin acylation to occur in the $6^{\prime \prime}-\mathrm{OH}$ portion of glucose, the primary alcohol [39-42], resulting in the production of only monoester [43]. As a result of this study, when vinyl acetate was used similar findings were observed as that of the previous study results. However, when acetic anhydride was used, different results were obtained. LC-MS was performed for qualitative analysis; its results showed [M + Na] in all cases (Figure 3). Diester was formed at $m / z 687.2$ and was seen as a new peak when acetic anhydride was used. A similar diester was produced in a previous 
study [12]. It was reported that acylation may occur in the $6^{\prime \prime}-\mathrm{OH}$ and $4^{\prime \prime \prime}-\mathrm{OH}$ portions of the rhamnoglucoside of naringin.
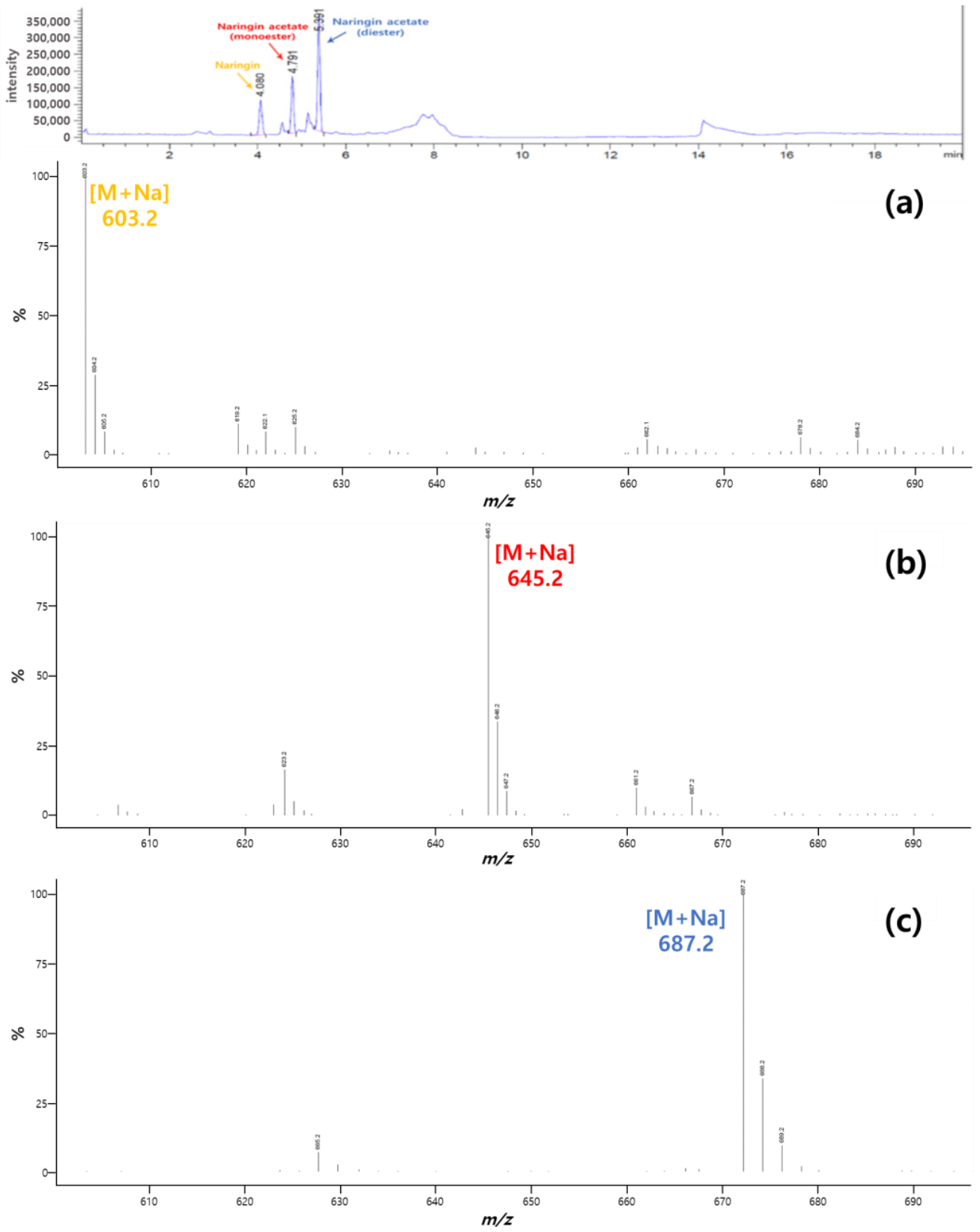

Figure 3. Results of the LC-MS analysis of naringin acetate: (a) naringin; (b) naringin acetate (monoester); (c) naringin acetate (diester).

\subsection{Selection of Enzyme}

Novozym 435, Lipozyme TL IM, and Lipozyme RM IM were screened to identify the enzyme best suited for naringin acetate synthesis. Lipases are generally classified according to their origin or specificity, with the latter including substrate specificity, regioselectivity, and stereospecificity. Novozym 435 originated from Candida antarctica lipase B (CALB), which is nonspecific, and was immobilized on a hydrophobic carrier acrylic resin. Lipozyme TL IM is a 1,3-specific lipase from Thermomyces lanuginosus, immobilized on silica gel. Lipozyme RM IM is a 1,3-specific lipase from Rhizomucor miehei, immobilized with a weak anion-exchange resin based on a phenol-formaldehyde copolymer. 
When Novozym 435, Lipozyme TL IM, and Lipozyme RM IM were used, conversions of $17.06 \%, 29.89 \%$, and $19.91 \%$ were obtained, respectively (Table 2). Lipozyme TL IM showed the highest conversion, which is consistent with other studies wherein naringin ester or flavonoid ester showed a high conversion with a Lipozyme TL IM catalyst $[12,14,32,44,45]$. Lipozyme TL IM is very effective in transesterification and is known to have high substrate selectivity for bulky groups in alcohol and acid moieties [46]. Meanwhile, Novozym 435 shows a better stability in the presence of low-molecular alcohol [47]. However, Lipozyme TL IM is eight and ten times less expensive than Lipozyme RM IM and Novozym 435, respectively [14,48]. Therefore, Lipozyme TL IM was considered a suitable enzyme from an efficient and economical viewpoint.

Table 2. Information on immobilized lipase and the corresponding conversion rate of naringin acetate.

\begin{tabular}{cccc}
\hline $\begin{array}{c}\text { Immobilized Lipase } \\
\text { (Regioselectivity) }\end{array}$ & Source & Support & Conversion (\%) \\
\hline $\begin{array}{c}\text { Novozym 435 } \\
\text { (Nonspecific) }\end{array}$ & Candida antarctica lipase B & Acrylic resin & $17.06 \pm 0.72$ \\
\hline $\begin{array}{c}\text { Lipozyme TL IM } \\
(1,3-s p e c i f i c)\end{array}$ & Thermomyces lanuginosus & Silica resin & $29.89 \pm 0.07$ \\
\hline $\begin{array}{c}\text { Lipozyme RM IM } \\
(1,3-s p e c i f i c)\end{array}$ & Rhizomucor miehei & Anion-exchange resin & $19.91 \pm 0.20$
\end{tabular}

(5g/L of the enzyme, vinyl acetate as the acyl donor, 1:1 molar ratio of naringin to acyl donor, reaction temperature of $40^{\circ} \mathrm{C}$, tert-amyl alcohol as the solvent, and reaction time of $48 \mathrm{~h}$ ).

\subsection{Effect of Enzyme Concentration on the Conversion of Naringin Acetate}

As the amount of enzyme is an important economic factor, it is vital to obtain maximum efficiency using a small amount of enzyme. Therefore, to assess the production of naringin acetate according to the amount of enzyme, the concentration of Lipozyme TL IM was set to $1,3,5,7$, and $9 \mathrm{~g} / \mathrm{L}$. In our basal experiment, a control experiment without an enzyme was performed under the same reaction conditions. As a result, the conversion was less than $1 \%$, and it was confirmed that the reaction did not proceed without the enzyme. Conversion in the presence of $1 \mathrm{~g} / \mathrm{L}$ and $3 \mathrm{~g} / \mathrm{L}$ increased to $22.77 \%$ and $33.48 \%$, while that in the presence of $5 \mathrm{~g} / \mathrm{L}$ decreased to $29.89 \%$. The conversion reduced continuously thereafter, being $27.60 \%$ and $26.29 \%$ at $7 \mathrm{~g} / \mathrm{L}$ and $9 \mathrm{~g} / \mathrm{L}$, respectively (Figure 4 ). Thus, $3 \mathrm{~g} / \mathrm{L}$ was determined as the optimum enzyme concentration.

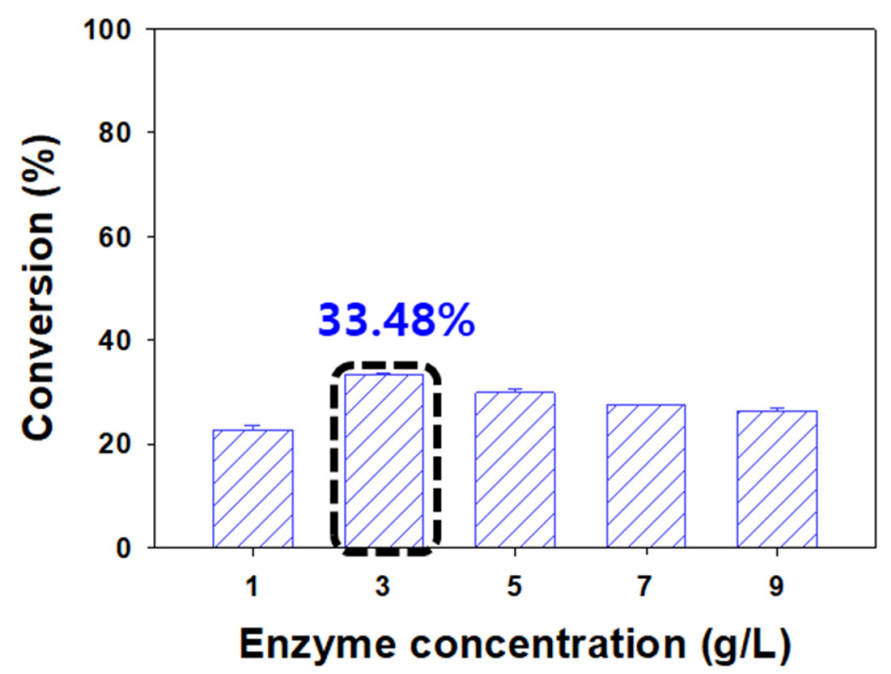

Figure 4. Effect of enzyme concentration. (Lipozyme TL IM, vinyl acetate as the acyl donor, 1:1 molar ratio of naringin to acyl donor, reaction temperature of $40^{\circ} \mathrm{C}$, tert-amyl alcohol as the solvent, and reaction time of $48 \mathrm{~h}$ ). 
In an enzymatic reaction, a specific substrate and the active site of the enzyme are combined to form an enzyme-substrate complex, which initiates the reaction $[14,20]$. When the enzyme concentration is low, fewer active sites of enzymes are available to be used by the substrate; therefore, the conversion increases with the increased enzyme. According to the Michaelis-Menten equation, if the amount of enzyme relative to the substrate is small, the substrate becomes excessive, and the initial reaction rate increases after the enzyme concentration is increased [21,22,49]. Meanwhile, when the enzyme is present in excess, the excess active site is not exposed to the substrate [14,50,51], and the formation of the enzymesubstrate complex does not increase [48,51]. In addition, when the immobilized enzyme particles are present in excess, the dispersion power of the enzyme molecules decreases along with the number of effective collisions between molecules, thereby reducing the mass transfer rate [52-54]. A study on the external diffusion effect of an immobilized enzyme reaction revealed that the surface concentration of the substrate increases with the increase in the mass transfer rate, while the surface concentration of the product decreases in that order [55]. The concentration of the substrate or product is directly related to the rate of diffusion, which causes a change in the motion constant and impacts conversion. Hari Krishna et al. [50] reported the synthesis of isoamyl acetate using Lipozyme TL IM and found that the initial reaction rate decreased with an increase in enzyme concentration, with no difference observed in the conversion after $3 \mathrm{~g} / \mathrm{L}$. The authors had explained that when the enzyme is present in excess, excess active sites are not exposed to the substrate, and hence do not contribute to the reaction [14,20-22]. This is similar to our observation of a slight decrease in conversion at an enzyme concentration of $3 \mathrm{~g} / \mathrm{L}$.

\subsection{Effects of Acyl Donors on the Conversion of Naringin Acetate}

Naringin acetate is synthesized by the nucleophilic acyl substitution reaction between naringin and an acyl donor. To determine the effects of the acyl donors, experiments were conducted using acetic acid, acetic anhydride, methyl acetate, vinyl acetate, ethyl acetate, propyl acetate, and butyl acetate. Results showed a high conversion rate of $36.91 \%$ and $33.48 \%$ for acetic anhydride and vinyl acetate, respectively (Table 3 ). Therefore, we selected vinyl acetate and acetic anhydride as optimal acyl donors.

Table 3. Information on acyl donors and the corresponding conversion rate of naringin acetate.

\begin{tabular}{|c|c|c|c|c|}
\hline Acyl Donor & Molecular Formula & Structure & Molecular Weight (g/mol) & Conversion $(\%)$ \\
\hline Acetic acid & $\mathrm{C}_{2} \mathrm{H}_{4} \mathrm{O}_{2}$ & & 60.05 & $15.60 \pm 0.24$ \\
\hline Acetic anhydride & $\mathrm{C}_{4} \mathrm{H}_{6} \mathrm{O}_{3}$ & & 102.09 & $36.91 \pm 0.35$ \\
\hline Methyl acetate & $\mathrm{C}_{3} \mathrm{H}_{6} \mathrm{O}_{2}$ & & 74.08 & $20.67 \pm 0.90$ \\
\hline Vinyl acetate & $\mathrm{C}_{4} \mathrm{H}_{6} \mathrm{O}_{2}$ & & 86.09 & $33.48 \pm 0.28$ \\
\hline Ethyl acetate & $\mathrm{C}_{4} \mathrm{H}_{8} \mathrm{O}_{2}$ & & 88.11 & $17.07 \pm 1.04$ \\
\hline
\end{tabular}


Table 3. Cont.

\begin{tabular}{cccc}
\hline Acyl Donor & Molecular Formula & Structure & Molecular Weight (g/mol) \\
Propyl acetate & $\mathrm{C}_{5} \mathrm{H}_{10} \mathrm{O}_{2}$ & Conversion (\%) \\
Butyl acetate & $\mathrm{C}_{6} \mathrm{H}_{12} \mathrm{O}_{2}$ &
\end{tabular}

(3 g/L of Lipozyme TL IM, 1:1 molar ratio of naringin to acyl donor, reaction temperature of $40^{\circ} \mathrm{C}$, tert-amyl alcohol as the solvent, and reaction time of $48 \mathrm{~h}$ ).

Acyl donor is a carbonyl compound with the electronegative atom as a leaving group. The stronger the leaving group, the more stable it is, by providing more electron pairs. However, the more stable it is, the lower its capacity to act as a leaving group. In general, the ability of the leaving group follows the order: acid chloride $>$ anhydride $>$ carboxylic acid $=$ ester $>$ amide. Therefore, anhydrides are more reactive than esters. In addition, as acetic anhydride has two carbonyl groups, it can perform a complex reaction $[56,57]$. First, it reacts with naringin to synthesize naringin acetate, with acetic acid produced as a by-product. The produced acetic acid, as a new acyl donor, reacts with the remaining naringin to further synthesize naringin acetate. Therefore, the highest conversion could be obtained with acetic anhydride as the acyl donor. Previous studies have reported the use of vinyl acetate as an acyl donor to produce various flavonoid acetates, including naringin acetate $[10,58,59]$. However, to date, the utilization of acetic anhydride as an acyl donor in flavonoid ester synthesis has not been reported, and this is the first study to do so.

Vinyl acetate also showed a high conversion rate, which can be explained by the tautomerization of by-products. When vinyl acetate is used as an acyl donor, vinyl alcohol is produced as a by-product, which is highly unstable in the form of an enol and is immediately converted to acetaldehyde by tautomerization. According to the results of Kim et al., by-products generated from the reaction could interfere with the reverse reaction, resulting in an irreversible flow $[42,56]$.

By-products including residual acetaldehyde can be removed through purification steps. Zheng et al., reported that naringin esters were synthesized by the reaction of naringin with fatty acids, and that the high purity $(>97 \%)$ of naringin esters was finally achieved through purification by two-step solvent extraction [27]. In this study, we focused on the effect of acyl donor on the synthesis of naringin acetate, and in our next study we will perform the optimization of the purification process to increase the purity of the target compound.

\subsection{Effects of Molar Ratio and Reaction Temperature on the Conversion of Naringin Acetate}

Substrate concentration is an important factor in an enzymatic reaction [14,20-22,25]; therefore, we conducted experiments by altering the molar ratio of the reactants. We altered the molar ratio of naringin and the acyl donor $(1: 1,1: 3,1: 5,1: 7,1: 9$, and 1:11) and determined its effect on the conversion of naringin acetate (Figure 5a). The enzymatic reaction was conducted at $40{ }^{\circ} \mathrm{C}$ using $3 \mathrm{~g} / \mathrm{L}$ Lipozyme TL IM with tert-amyl alcohol for $48 \mathrm{~h}$.

In the case of acetic anhydride, the conversion increased significantly to $36.91 \%$ and $75.72 \%$ at $1: 1$ and $1: 3$, respectively, and increased further to $86.63 \%$ at $1: 5$. Thereafter, conversions of $85.61 \%, 86.41 \%$, and $87.19 \%$ were obtained at $1: 7,1: 9$, and $1: 11$, and were similar to that at 1:5.

In the case of vinyl acetate, the conversion increased to $33.48 \%, 70.29 \%$, and $94.47 \%$ at 1:1,1:3, and 1:5, respectively. Thereafter, a $96.07 \%, 96.55 \%$, and $96.70 \%$ conversion was 
obtained at 1:7, 1:9, and 1:11, respectively. As seen for acetic anhydride, the results obtained with vinyl acetate did not change significantly at molar ratios below 1:5.
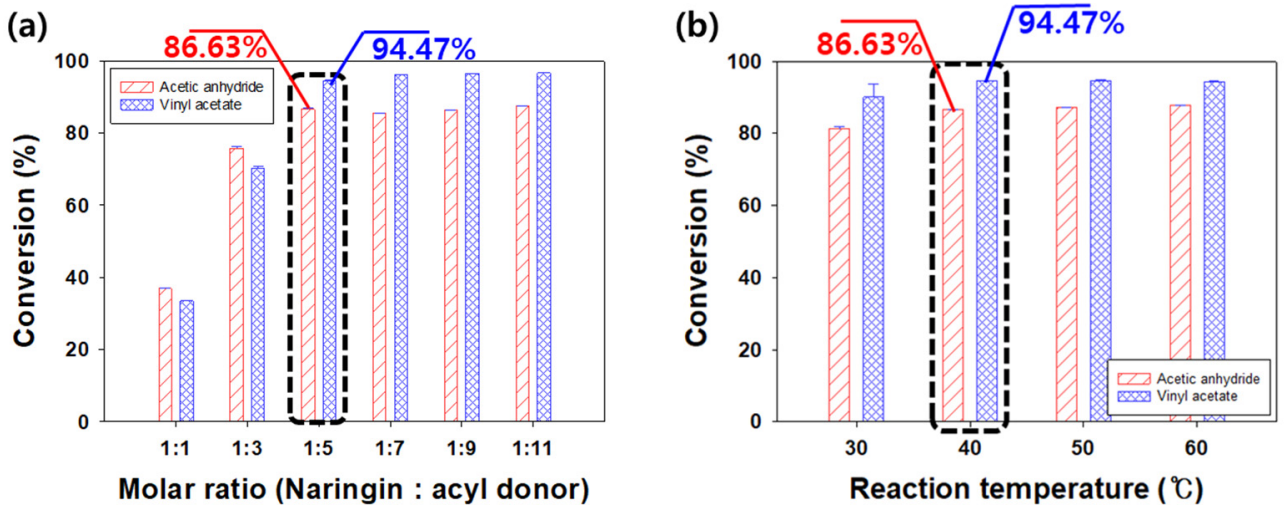

Figure 5. Effects of molar ratio between naringin and acyl donor (a), and reaction temperature on the conversion of naringin acetate $(\mathbf{b})$.

As transesterification using lipase is a reversible reaction, an excessive acyl donor concentration is required for the reaction equilibrium to shift to transesterification $[25,56]$. The mechanism of transesterification of the acyl donor and naringin through lipase is as follows. First, serine as a nucleophile at the active site of lipase attacks the acyl donor to form a tetrahedral intermediate. The latter attacks histidine, resulting in the formation of a byproduct. Next, the alcohol of naringin, as a nucleophile, attacks the intermediate, creating a new tetrahedral intermediate. Thereafter, the product naringin acetate is produced by the movement of electrons, and the active site of lipase returns to its original state. According to the mechanism [20-22,60], the acyl donor reacts with the enzyme first and then naringin reacts to form naringin acetate. If there is an excess of acyl donor, it will react more with the active site of the enzyme to form an intermediate, which then reacts with naringin to increase the conversion of naringin acetate. However, if an excessive amount of naringin is present, it binds to the active site of lipase and competitively inhibits it, forming a dead-end complex $[14,60,61]$. Chebil et al. had conducted experiments by varying the molar ratio of vinyl acetate/quercetin to 5, 10, 20, and 40, and reported conversions of $55 \%, 88 \%, 96 \%$, and $96 \%$, respectively [59]. As the ratio of vinyl acetate increased, the conversion rate also increased, before finally saturating. Due to the excess vinyl acetate, the molar ratio of the substrate was considered to affect the thermodynamic shift of equilibrium.

When the molar ratio of naringin to acyl donors was 1:5 or lower $(1: 7,1: 9$, and 1:11), according to the increasing concentration of the acyl donor, the conversion was greater with vinyl acetate than with acetic anhydride. When acetic anhydride reacts with naringin, acetic acid is produced as a by-product. Since acetic acid is a strong acid, it can act as an inhibitor of enzyme activity, causing dead-end inhibition, and can inactivate enzymes by acidifying the micro-aqueous layer of the enzyme [49]. In the presence of excess acetic anhydride, acetic acid production was increased as a by-product. Beyond the molar ratio of 1:5, acetic anhydride appeared to have a lower conversion than vinyl acetate owing to the formation of acetic acid.

In an enzymatic reaction, temperature is a vital factor, influencing the activity and denaturation of the enzyme as well as the substrate solubility. As the temperature rises, collisions between enzymes and substrate molecules increase, which increase the reaction rate. In addition, as the reaction temperature increases, the viscosity of the solution decreases, and the solubility of the substrate and product increases [20-22,62,63]. However, at very high temperatures, the non-covalent bonds that stabilize the three-dimensional structure of the protein may be weakened, and the activity of the enzyme may be lost $[56,64]$.

Our experiments were conducted at 30,40,50, and $60{ }^{\circ} \mathrm{C}$ using $3 \mathrm{~g} / \mathrm{L}$ Lipozyme TL IM with tert-amyl alcohol under the determined molar ratio (1:5) for $48 \mathrm{~h}$. We aimed to 
determine the effect of the reaction's temperature on the production of naringin acetate; the results with acetic anhydride showed conversions of $81.25 \%$ at $30{ }^{\circ} \mathrm{C}$ and $86.63 \%, 87.13 \%$, and $87.68 \%$ at 40,50 , and $60{ }^{\circ} \mathrm{C}$, respectively, which was a slight difference. The conversions rate obtained with vinyl acetate were $90.03 \%, 94.47 \%, 94.65 \%$, and $94.40 \%$, respectively, similar to that with acetic anhydride (Figure $5 b$ ).

Based on the above results, the change in conversion was large when the temperature was increased from $30{ }^{\circ} \mathrm{C}$ to $40^{\circ} \mathrm{C}$, with only minimal changes observed thereafter. Therefore, the solubility of the substrate had the greatest influence on this reaction. Qian et al. investigated the effect of temperature in the range of $40-60{ }^{\circ} \mathrm{C}$ on the synthesis of isoorientin ester using free Candida rugosa lipase [65]. The conversion was observed to increase rapidly at $50{ }^{\circ} \mathrm{C}$, with the maximum conversion of $62.6 \%$ obtained at $60{ }^{\circ} \mathrm{C}$, and decrease sharply thereafter to $31 \%$ at $65^{\circ} \mathrm{C}$. They reported the solubility of isoorientin in the reaction system to increase with increased temperature. Khor et al. investigated the effect of the reaction's temperature on biodiesel synthesis using Lipozyme TL IM [64]. Similar to our current findings, the reaction rate was reported to be increased when the temperature increased from 30 to $40{ }^{\circ} \mathrm{C}$, and the optimum reaction temperature was $40{ }^{\circ} \mathrm{C}[14,64]$.

\subsection{Effect of Solvent on the Conversion of Naringin Acetate}

The use of organic solvents in the reaction medium shifts the thermodynamic equilibrium such that it favors ester synthesis over hydrolysis. In addition, most organic solvents have a lower boiling point than aqueous media, and hence are readily removed, being advantageous in the separation and purification processes [15,20-22]. This study used an organic solvent as the reaction medium to induce ester synthesis. Organic solvents affect the activity, stability, and denaturation of the enzyme. They also affect the solubility, regioselectivity, and stereoselectivity of the substrate. Therefore, the conversion of naringin acetate depending on the type of organic solvent was next evaluated. Lipase is known to exhibit a high activity and stability in hydrophobic organic solvents. However, hydrophobic solvents are not suitable for the synthesis of hydrophilic hydrocarbons or sugar esters [66]. Therefore, relatively hydrophilic organic solvents, such as acetonitrile, 1,4-dioxane, acetone, THF, tert-butyl alcohol, tert-amyl alcohol, and 1,2-dichloroethane were screened in this study.

When acetic anhydride was used as an acyl donor, the highest conversion was $98.51 \%$ in acetonitrile. Acetone and THF showed similar conversions, of $98.37 \%$ and $98.20 \%$, whereas 1,2-dichloroethane showed the lowest conversion, of $18.03 \%$.

When vinyl acetate was used as the acyl donor, the highest conversion was obtained with acetonitrile (98.49\%), followed by tert-amyl alcohol and tert-butyl alcohol $(94.47 \%$ and $91.16 \%$, respectively). Similar to acetic anhydride, 1,2-dichloroethane showed the lowest conversion, of $37.32 \%$ (Table 4 ).

Table 4. Information on organic solvents and the corresponding conversion of naringin acetate.

\begin{tabular}{ccccc}
\hline Organic Solvent & $\log \boldsymbol{p}$ & Dielectric Constant & Conversion (\%) $^{\mathbf{a}}$ & Conversion (\%) $^{\mathbf{b}}$ \\
\hline Acetonitrile & -0.33 & 37.5 & $98.51 \pm 0.01$ & $98.49 \pm 0.01$ \\
\hline 1,4-Dioxane & -0.27 & 2.25 & $89.96 \pm 0.19$ & $78.36 \pm 1.52$ \\
\hline Acetone & -0.16 & 20.7 & $98.37 \pm 0.03$ & $75.67 \pm 0.04$ \\
\hline THF & 0.49 & 7.5 & $98.20 \pm 0.02$ & $88.30 \pm 3.99$ \\
\hline tert-Butyl alcohol & 0.58 & 10.9 & $81.11 \pm 0.46$ & $91.16 \pm 0.23$ \\
\hline tert-Amyl alcohol & 1.09 & 5.78 & $86.63 \pm 0.27$ & $94.47 \pm 0.02$ \\
\hline 1,2-Dichloroethane & 1.48 & 10.4 & $16.01 \pm 2.85$ & $37.32 \pm 3.21$ \\
\hline
\end{tabular}

(a: $3 \mathrm{~g} / \mathrm{L}$ of Lipozyme TL IM, acetic anhydride as the acyl donor, 1:5 molar ratio of naringin to acetic anhydride, reaction temperature of $40{ }^{\circ} \mathrm{C}$, and reaction time of $48 \mathrm{~h} ; \mathrm{b}: 3 \mathrm{~g} / \mathrm{L}$ of Lipozyme TL IM, vinyl acetate as the acyl donor, 1:5 molar ratio of naringin to vinyl acetate, reaction temperature of $40{ }^{\circ} \mathrm{C}$, and reaction time of $48 \mathrm{~h}$ ). 
$\log p$ is the logarithm value of the partition coefficient between water and octanol, representing the degree of hydrophobicity. The larger the $\log p$ value, the higher the hydrophobicity. The $\log p$ value of naringin was -0.44 , whereas those of acetic anhydride and vinyl acetate were -0.27 and 0.73 , respectively. The various reaction solvents examined, along with their $\log p$ values, were: acetonitrile $(-0.33), 1,4$-dioxane $(-0.27)$, acetone (-0.16), THF (0.49), tert-butyl alcohol (0.58), tert-amyl alcohol (1.09), and 1,2-dichloroethane (1.48). A $\log p$ value $<2$ indicates a hydrophilic organic solvent, whereas a value $\geq 4$ indicates a hydrophobic organic solvent [20-22,67]. The dielectric constant represents solvent polarizability. In general, a high dielectric constant refers to polar solvents, while a low dielectric constant refers to non-polar solvents. Based on the increasing dielectric constant values, the reaction solvents could be arranged in the following order: 1,4-dioxane (2.25), tert-amyl alcohol (5.78), THF (7.5), 1,2-dichloroethane (10.4), tert-butyl alcohol (10.9), acetone (20.7), and acetonitrile (37.5).

In lipase-based reactions, such as biodiesel synthesis, hydrophobic solvents such as hexane and toluene are used. However, naringin is a polar, hydrophilic material with a very low $\log p$ value and does not dissolve in a hydrophobic solvent. Previous studies using Novozym 435 had shown it to be stable in hydrophilic solvents, such as acetonitrile or acetone [68]. From the results of the current study, Lipozyme TL IM was also confirmed to be stable in a hydrophilic organic solvent. Milisavljevic et al. had reported a $54.65 \%, 28.98 \%$, and $15.72 \%$ conversion using acetonitrile, acetone, and tert-butyl alcohol, respectively, in the synthesis of phloridzil oleate [68]. The use of isooctane and dodecane showed very low conversions due to their low solubility in hydrophobic media. The current study showed the highest conversion in acetonitrile and a remarkably low conversion in relatively hydrophobic 1,2-dichloroethane. The solubility of naringin was low in 1,2-dichloroethane, and the reaction did not occur in more hydrophobic solvents (hexane, toluene, etc.), as it did not dissolve in these solvents. Hazarika et al. had investigated the influence of the hydrophobicity, polarization rate, and water solubility of the solvent on the initial reaction rate of the lipase reaction [69] and found less hydrophobic solvents, i.e., those with a low $\log p$ value, to have a high initial reaction rate, as the substrate was more partitioned between the active site of lipase and the solvent. In addition, the enzyme remained tighter at a low dielectric constant than at a high dielectric constant. For the initial reaction rate, the degree of hydrophobicity was judged as the most important factor, and the polar solvent was found to be a good reaction solvent in the transesterification reaction. The optimal solvent selected in this study was acetonitrile, with a very $\operatorname{low} \log p$ value of -0.33 and a high dielectric constant of 37.5, making it a polar, hydrophilic solvent.

The conversion with respect to reaction time was investigated under the optimal conditions obtained through the OFAT method described above (Figure 6). The reaction was completed within $8 \mathrm{~h}$ when acetic anhydride was used, and within $24 \mathrm{~h}$ when vinyl acetate was used; each conversion was $98.51 \%$ and $97.54 \%$, respectively. When acetic anhydride was used, the reaction appeared to be faster, since two reactions could occur. In a previous study by Romero et al., the synthesis of isoamyl acetate was confirmed to be faster with acetic anhydride than with any other acyl donor [49]. Previous studies on the synthesis of flavonoid esters required a long reaction time of more than $96 \mathrm{~h}[6,10,26-28,37,68,70,71]$. Comparing the previous studies with the current one, the reaction time was found to be indeed shortened.

Table 5 summarizes the reaction conditions used in various studies to synthesize naringin esters through the enzymatic reaction of naringin and various acyl donors. Large amounts of enzyme and acyl donor were used in many studies, and a low conversion was obtained after a long reaction time. In contrast, this study used a small amount of enzyme (Lipozyme TL IM) and acyl donor (acetic anhydride or vinyl acetate) for the synthesis of naringin ester, and a high conversion was obtained in a short reaction time. 


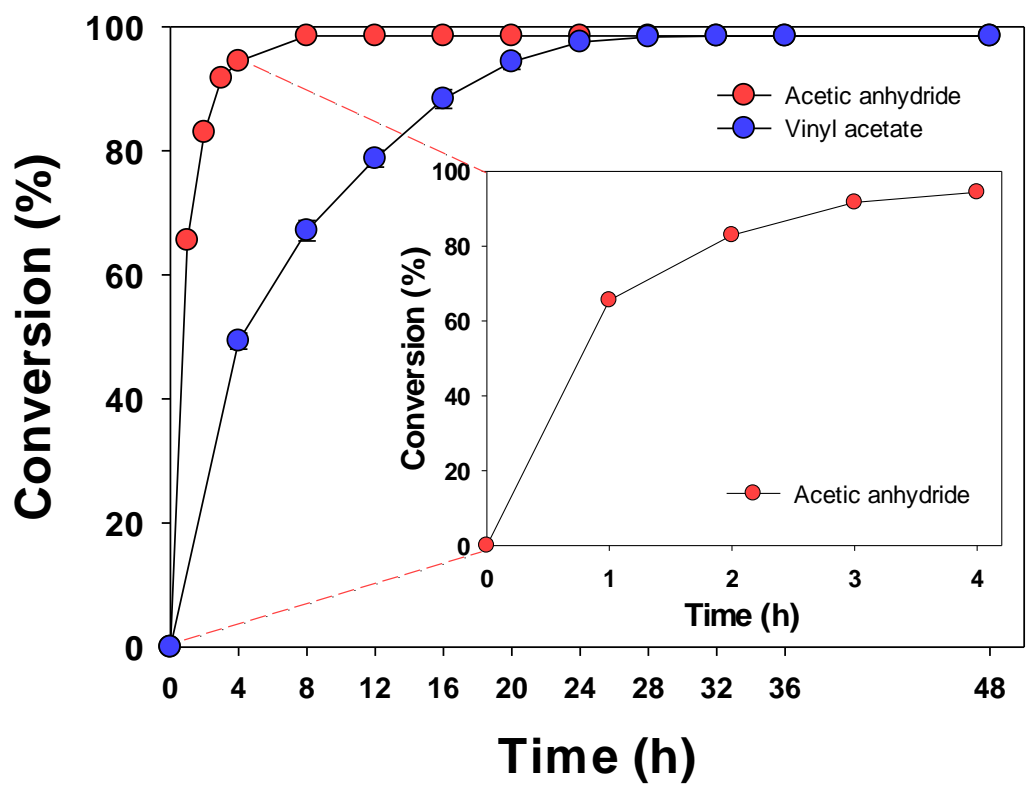

Figure 6. Conversion of naringin acetate as a function of reaction time ( $3 \mathrm{~g} / \mathrm{L}$ of Lipozyme TL IM, acetic anhydride or vinyl acetate as the acyl donor, 1:5 molar ratio of naringin to acyl donor, reaction temperature of $40^{\circ} \mathrm{C}$, acetonitrile as the solvent, and reaction time of $48 \mathrm{~h}$ ).

Table 5. Summary of reaction conditions for the synthesis of naringin esters by lipase.

\begin{tabular}{|c|c|c|c|c|c|c|}
\hline Acyl Donor & Enzyme & Enzyme Conc., Molar Ratio & Solvent & Reaction & Conversion & Ref. \\
\hline \multicolumn{7}{|c|}{ (Naringin: Acyl Donor) } \\
\hline Vinyl acetate & Whole-cell catalyst & Whole-cell $50 \mathrm{mg} / \mathrm{mL}, 1: 50$ & Organic solvent & $50^{\circ} \mathrm{C}, 96 \mathrm{~h}$ & $41.03 \%$ & [10] \\
\hline Vinyl octanoate & Aspergillus oryzae & & & & $91.40 \%$ & \\
\hline Vinyl butyrate & Novozym 435 & Enzyme $80 \mathrm{~g} / \mathrm{L}, 1: 10$ & Acetone & $60^{\circ} \mathrm{C}, 144 \mathrm{~h}$ & $90 \%$ & [12] \\
\hline \multirow[t]{2}{*}{ Oleic acid } & Lipozyme TL IM & Enzyme $10 \mathrm{~g} / \mathrm{L}, 1: 20$ & Acetonitrile & $40^{\circ} \mathrm{C}, 48 \mathrm{~h}$ & $93.10 \%$ & {$[14]$} \\
\hline & & & & $40{ }^{\circ} \mathrm{C}, 24 \mathrm{~h}$ & $92.17 \%$ & \\
\hline Coconut oil & Novozym 435 & Enzyme $5 \mathrm{~g} / \mathrm{L}, 1: 6$ & Acetonitrile & $65^{\circ} \mathrm{C}, 90 \mathrm{~h}$ & $75.43 \%$ & {$[25]$} \\
\hline Linseed oil & & & & & $76.70 \%$ & \\
\hline Sunflower oil & & & & & $85.08 \%$ & \\
\hline Ricinoleic acid & Novozym 435 & Enzyme $20 \mathrm{~g} / \mathrm{L}, 1: 3$ & Acetone & $50^{\circ} \mathrm{C}, 120 \mathrm{~h}$ & $33 \%$ & [26] \\
\hline Oleic acid & Novozym 435 & Enzyme $15 \mathrm{~g} / \mathrm{L}, 1: 4$ & $\begin{array}{l}\text { Acetone: tert-amyl } \\
\text { alcohol }(2: 1)\end{array}$ & $50^{\circ} \mathrm{C}, 96 \mathrm{~h}$ & $78.4 \%$ & [27] \\
\hline Linoleic acid & & & & & $77.6 \%$ & \\
\hline Linolenic acid & & & & & $86.6 \%$ & \\
\hline Lauric acid & Novozym 435 & Enzyme $12 \mathrm{~g} / \mathrm{L}, 1: 5$ & Acetone & $45^{\circ} \mathrm{C}, 96 \mathrm{~h}$ & $80-90 \%$ & [28] \\
\hline \multicolumn{7}{|l|}{ Oleic acid } \\
\hline \multicolumn{7}{|l|}{ Linolenic acid } \\
\hline Vinyl laurate & Novozym 435 & Enzyme $17 \mathrm{~g} / \mathrm{L}, 1: 10$ & Acetonitrile & $50{ }^{\circ} \mathrm{C}, 8 \mathrm{~h}$ & $50 \%$ & [29] \\
\hline Acetic anhydride & Lipozyme TL IM & Enzyme $3 \mathrm{~g} / \mathrm{L}, 1: 5$ & Acetonitrile & $40^{\circ} \mathrm{C}, 8 \mathrm{~h}$ & $98.51 \%$ & This study \\
\hline Vinyl acetate & Lipozyme TL IM & Enzyme $3 \mathrm{~g} / \mathrm{L}, 1: 5$ & Acetonitrile & $40^{\circ} \mathrm{C}, 24 \mathrm{~h}$ & $97.54 \%$ & This study \\
\hline
\end{tabular}

Based on the selection of major variables and the determination of optimal conditions, a significant conversion of approximately $98 \%$ of naringin acetate was achieved, starting from a conversion of less than $30 \%$. In particular, when acetic anhydride is used as the acyl donor, the reaction time can be significantly shortened to within $8 \mathrm{~h}$, and it can be confirmed that the conversion is at the highest level compared to previous reports. Naringin esters 
with improved bioavailability through acylation have a high potential in various fields such as food, cosmetics, and pharmaceuticals, but there are barriers to industrial applications due to a low conversion and a long reaction time. The improved enzymatic conversion and reaction time obtained through the conditions used in this study will contribute to the commercialization of naringin acetate. In the future, the evaluation of enzyme reuse based on stability will be performed under the determined reaction conditions, and it is expected that a completed enzymatic conversion process will be derived.

\section{Conclusions}

This study aimed to improve the enzymatic conversion of naringin acetate by screening important variables and determining the optimal reaction conditions. Under optimal conditions, the maximum conversions from acetic anhydride and vinyl acetate were found to be $98.5 \%(8 \mathrm{~h})$ and $97.5 \%(24 \mathrm{~h})$, respectively. The use of acetic anhydride as an acyl donor and Lipozyme TL IM as a biocatalyst was first attempted in the study of naringin acetate. Compared with the previous study, a high conversion rate could be achieved in a relatively short reaction time through the optimization of important variables. These results could potentially contribute to the economical and efficient synthesis of flavonoid esters using enzymes.

Author Contributions: Conceptualization, C.P. and H.Y.Y.; methodology, Y.B. and S.L.; validation, Y.B. and J.S.; formal analysis, T.L. and J.-M.O.; investigation, Y.B., S.H.L. and H.U.K.; resources, S.J.P. and H.Y.Y.; data curation, Y.B. and H.U.K.; writing-original draft preparation, C.P. and Y.B.; writing-review and editing, Y.B., T.L., H.Y.Y. and C.P.; supervision, C.P.; project administration, S.W.S. and C.P.; funding acquisition, H.U.K., S.W.S., S.J.P. and C.P. All authors have read and agreed to the published version of the manuscript.

Funding: This study was supported by the Mid-Career Researcher Program of the National Research Foundation of Korea (NRF) funded by the Ministry of Science and ICT (MSIT) [NRF-2020R1A2C1007493], the Bio \& Medical Technology Development Program of the NRF funded by the MSIT [NRF2018M3A9H3020459], and the Korea Institute for Advancement of Technology (KIAT) grant funded by the Korean Government (MOTIE) [P0012451].

Institutional Review Board Statement: Not applicable.

Informed Consent Statement: Not applicable.

Data Availability Statement: The data are contained within the article.

Conflicts of Interest: The authors declare no conflict of interest.

\section{References}

1. Panche, A.N.; Diwan, A.D.; Chandra, S.R. Flavonoids: An overview. J. Nutr. Sci. 2016, 5, E47. [CrossRef] [PubMed]

2. Viskupicova, J.; Maliar, T. Rutin fatty acid esters: From synthesis to biological health effects and application. J. Food Nutr. Res. 2017, 56, 232-243.

3. Kim, W.; Lee, J.K.; Choi, K.Y.; Kim, B.G.; Kim, J. Regioselective biotransformation of phloretin using Streptomyces avermitilis MA4680. Biotechnol. Bioprocess Eng. 2020, 25, 272-278. [CrossRef]

4. Jung, U.J.; Kim, H.J.; Lee, J.S.; Lee, M.K.; Kim, H.O.; Park, E.J.; Kim, H.K.; Jeong, T.S.; Choi, M.S. Naringin supplementation lowers plasma lipids and enhances erythrocyte antioxidant enzyme activities in hypercholesterolemic subjects. Clin. Nutr. 2003, 22, 561-568. [CrossRef]

5. Zhou, Z.; Fu, C. A new flavanone and other constituents from the rhizomes of Cyperus rotundus and their antioxidant activities. Chem. Nat. Compd. 2013, 48, 963-965. [CrossRef]

6. Cao, R.; Li, X.; Zhou, Z.; Zhao, Z. Synthesis and biophysical analysis of Naringin-Chitooligosaccharide complex. Nat. Prod. Res. 2019, 35, 305-311. [CrossRef]

7. Szliszka, E.; Kostrzewa-Susłow, E.; Bronikowska, J.; Jaworska, D.; Janeczko, T.; Czuba, Z.P.; Krol, W. Synthetic flavanones augment the anticancer effect of tumor necrosis factor-related apoptosis-inducing ligand (TRAIL). Molecules 2012, 17, 11693-11711. [CrossRef]

8. Fisher, J.F.; Wheaton, T.A. A high-pressure liquid chromatographic method for the resolution and quantitation of naringin and naringenin rutinoside in grapefruit Juice. J. Agric. Food Chem. 1976, 24, 898-899. [CrossRef]

9. Sharma, S.; Ali, A.; Ali, J.; Sahni, J.K.; Baboota, S. Rutin: Therapeutic potential and recent advances in drug delivery. Expert Opin. Investig. Drugs 2013, 22, 1063-1079. [CrossRef] 
10. Li, X.; Zhao, Y.; Lai, X.; Nong, J.; Zhao, G.; Xiao, X. One-pot biocatalytic synthesis and antioxidant activities of highly lipophilic naringin derivatives by using bi-functional whole-cells. Food Res. Int. 2020, 136, 109291. [CrossRef]

11. Gullón, B.; Lú-Chau, T.A.; Moreira, M.T.; Lema, J.M.; Eibes, G. Rutin: A review on extraction, identification and purification methods, biological activities and approaches to enhance its bioavailability. Trends Food Sci. Technol. 2017, 67, 220-235. [CrossRef]

12. Katsoura, M.H.; Polydera, A.C.; Tsironis, L.; Tselepis, A.D.; Stamatis, H. Use of ionic liquids as media for the biocatalytic preparation of flavonoid derivatives with antioxidant potency. J. Biotechnol. 2006, 123, 491-503. [CrossRef] [PubMed]

13. Danihelová, M.; Viskupičová, J.; Šturdík, E. Lipophilization of flavonoids for their food, therapeutic and cosmetic applications. Acta Chim. Slovaca 2012, 5, 59-69. [CrossRef]

14. Lee, J.; Kim, K.; Son, J.; Lee, H.; Song, J.H.; Lee, T.; Jeon, H.; Kim, H.S.; Park, S.J.; Yoo, H.Y.; et al. Improved productivity of naringin oleate with flavonoid and fatty acid by efficient enzymatic esterification. Antioxidants 2022, 11, 242. [CrossRef] [PubMed]

15. Sharma, S.; Kanwar, S.S. Organic solvent tolerant lipases and applications. Sci. World J. 2014, 2014, 625258. [CrossRef]

16. Franco, Y.; Longato, G.; Carvalho, P.; Messias, M.; de Araújo, M.; Pamphile, J. Biocatalytic synthesis of flavonoid esters by lipases and their biological benefits. Planta Med. 2016, 83, 7-22. [CrossRef]

17. Rychlicka, M.; Maciejewska, G.; Niezgoda, N.; Gliszczyńska, A. Production of feruloylated lysophospholipids via a one-step enzymatic interesterification. Food Chem. 2020, 323, 126802. [CrossRef]

18. Okulus, M.; Gliszczyńska, A. Enzymatic synthesis of o-methylated phenophospholipids by lipase-catalyzed acidolysis of egg-yolk phosphatidylcholine with anisic and veratric acids. Catalysts 2020, 10, 538. [CrossRef]

19. Viskupičová, J.; Ondrejovic, M.; Maliar, T. Enzyme-mediated preparation of flavonoid esters and their applications. Biochemistry 2012, 10, 263-278. [CrossRef]

20. Shin, M.; Seo, J.; Baek, Y.; Lee, T.; Jang, M.; Park, C. Novel and efficient synthesis of phenethyl formate via enzymatic esterification of formic acid. Biomolecules 2020, 10, 70. [CrossRef]

21. Baek, Y.; Lee, J.; Son, J.; Lee, T.; Sobhan, A.; Lee, J.; Koo, S.M.; Shin, W.H.; Oh, J.M.; Park, C. Enzymatic synthesis of formate ester through immobilized lipase and its reuse. Polymers 2020, 12, 1802. [CrossRef] [PubMed]

22. Seo, J.; Shin, M.; Lee, J.; Lee, T.; Oh, J.M.; Park, C. Novel and highly efficient lipase-catalyzed esterification of formic acid with hexanol for waste gas reutilization. J. Ind. Eng. Chem. 2021, 93, 430-435. [CrossRef]

23. Liu, C.; Yang, Y.; Gao, H.; Bai, X.; Li, Z.J. Preparation and enzymatic activity of $\mathrm{Fe}_{3} \mathrm{O}_{4}$-IDA-Ni/NAD kinase magnetic catalyst. Korean J. Chem. Eng. 2020, 37, 475-481. [CrossRef]

24. Chun, J.; Sang, B.I. Enzymatic esterification under high-pressure $\mathrm{CO}_{2}$ conditions for in situ recovery of butyric acid from anaerobic fermenters. Biotechnol. Bioprocess Eng. 2020, 25, 616-622. [CrossRef]

25. Milivojević, A.D.; Ćorović, M.M.; Simović, M.B.; Banjanac, K.M.; Blagojević, S.N.; Pjanović, R.V.; Bezbradica, D.I. Novel approach for flavonoid esters production: Statistically optimized enzymatic synthesis using natural oils and application in cosmetics. Ind. Eng. Chem. Res. 2019, 58, 3640-3649. [CrossRef]

26. Almeida, V.M.; Branco, C.R.C.; Assis, S.A.; Vieira, I.J.C.; Braz-Filho, R.; Branco, A. Synthesis of naringin 6"-ricinoleate using immobilized lipase. Chem. Cent. J. 2012, 6, 41. [CrossRef]

27. Zheng, M.M.; Wang, L.; Huang, F.H.; Guo, P.M.; Wei, F.; Deng, Q.C.; Zheng, C.; Wan, C.Y. Ultrasound irradiation promoted lipase-catalyzed synthesis of flavonoid esters with unsaturated fatty acids. J. Mol. Catal. B Enzym. 2013, 95, 82-88. [CrossRef]

28. Sun, C.Q.; Johnson, K.D.; Wong, H.; Foo, L.Y. Biotransformation of flavonoid conjugates with fatty acids and evaluations of their functionalities. Front. Pharmacol. 2017, 8, 759. [CrossRef]

29. Céliz, G.; Daz, M. Biocatalytic preparation of alkyl esters of citrus flavanone glucoside prunin in organic media. Process Biochem. 2011, 46, 94-100. [CrossRef]

30. Degenhardt, A.; Ullrich, F.; Hofmann, T.; Stark, T. Flavonoid Sugar Addition Products, Method for Manufacture and Use Thereof. U.S. Patent 8,003,150, 23 August 2011.

31. Bok, S.-H.; Jeong, T.-S.; Lee, S.-K.; Kim, J.-R.; Moon, S.-S.; Choi, M.-S.; Hyun, B.-H.; Lee, C.-H.; Choi, Y.-K. Flavanone Derivatives and Composition for Preventing or Treating Blood Lipid Level-Related Diseases Comprising Same. U.S. Patent 6,455,577, 24 September 2002

32. Mellou, F.; Loutrari, H.; Stamatis, H.; Roussos, C.; Kolisis, F.N. Enzymatic esterification of flavonoids with unsaturated fatty acids: Effect of the novel esters on vascular endothelial growth factor release from K562 cells. Process Biochem. 2006, 41, $2029-2034$. [CrossRef]

33. Hattori, H.; Tsutsuki, H.; Nakazawa, M.; Ueda, M.; Ihara, H.; Sakamoto, T. Naringin lauroyl ester inhibits lipopolysaccharideinduced activation of nuclear factor $\mathrm{kB}$ signaling in macrophages. Biosci. Biotechnol. Biochem. 2016, 80, 1403-1409. [CrossRef] [PubMed]

34. Moussou, P.; Falcimaigne, A.; Ghoul, M.; Danoux, L.; Pauly, G. Esters of Flavonoids and w-Substituted C6-C22 Fatty. Acids Patent 2007/0,184,098, 9 August 2007.

35. Saija, A.; Tomaino, A.; Trombetta, D.; Pellegrino, M.L.; Tita, B.; Messina, C.; Bonina, F.P.; Rocco, C.; Nicolosi, G.; Castelli, F. "In vitro" antioxidant and photoprotective properties and interaction with model membranes of three new quercetin esters. Eur. J. Pharm. Biopharm. 2003, 56, 167-174. [CrossRef]

36. Viskupicova, J.; Danihelova, M.; Ondrejovic, M.; Liptaj, T.; Sturdik, E. Lipophilic rutin derivatives for antioxidant protection of oil-based foods. Food Chem. 2010, 123, 45-50. [CrossRef] 
37. Viskupicova, J.; Danihelova, M.; Majekova, M.; Liptaj, T.; Sturdik, E. Polyphenol fatty acid esters as serine protease inhibitors: A quantum-chemical QSAR analysis. J. Enzym. Inhib. Med. Chem. 2012, 27, 800-809. [CrossRef]

38. Razak, N.N.A.; Annuar, M.S.M. Enzymatic synthesis of flavonoid ester: Elucidation of its kinetic mechanism and equilibrium thermodynamic behavior. Ind. Eng. Chem. Res. 2015, 54, 5604-5612. [CrossRef]

39. Nakajima, N.; Ishihara, K.; Itoh, T.; Furuya, T.; Hamada, H. Lipase-catalyzed direct and regioselective acylation of flavonoid glucoside for mechanistic investigation of stable plant pigments. J. Biosci. Bioeng. 1999, 87, 105-107. [CrossRef]

40. Kontogianni, A.; Skouridou, V.; Sereti, V.; Stamatis, H.; Kolisis, F.N. Regioselective acylation of flavonoids catalyzed by lipase in low toxicity media. Eur. J. Lipid Sci. Technol. 2001, 103, 655-660. [CrossRef]

41. Kontogianni, A.; Skouridou, V.; Sereti, V.; Stamatis, H.; Kolisis, F.N. Lipase-catalyzed esterification of rutin and naringin with fatty acids of medium carbon chain. J. Mol. Catal. B Enzym. 2003, 21, 59-62. [CrossRef]

42. Mellou, F.; Lazari, D.; Skaltsa, H.; Tselepis, A.D.; Kolisis, F.N.; Stamatis, H. Biocatalytic preparation of acylated derivatives of flavonoid glycosides enhances their antioxidant and antimicrobial activity. J. Biotechnol. 2005, 116, 295-304. [CrossRef]

43. Danieli, B.; De Bellis, P.; Carrea, G.; Riva, S. Enzyme-mediated regioselective acylations of flavonoid disaccharide monoglycosides. Helv. Chim. Acta 1990, 73, 1837-1844. [CrossRef]

44. Du, L.; Jiang, Z.; Xu, L.; Zhou, N.; Shen, J.; Dong, Z.; Shen, L.; Wang, H.; Luo, X. Microfluidic reactor for lipase-catalyzed regioselective synthesis of neohesperidin ester derivatives and their antimicrobial activity research. Carbohydr. Res. 2018, 455, 32-38. [CrossRef]

45. Luo, X.P.; Du, L.H.; He, F.; Zhou, C.H. Controllable regioselective acylation of flavonoids catalyzed by lipase in microreactors. J. Carbohydr. Chem. 2013, 32, 450-462. [CrossRef]

46. Novozymes A/S. Immobilized Lipases for Biocatalysis for Smarter Chemical Synthesis. Available online: https://www. novozymes.com/- /media/Project/Novozymes/Website/website/document-library/Advance-your-business/Pharma/ Biocatalysis_brochure_Immobilised_Lipases.pdf (accessed on 20 December 2021).

47. Hernández-Martín, E.; Otero, C. Different enzyme requirements for the synthesis of biodiesel: Novozym ${ }^{\circledR} 435$ and Lipozyme ${ }^{\circledR}$ TL IM. Bioresour. Technol. 2008, 99, 277-286. [CrossRef] [PubMed]

48. Awang, R.; Basri, M.; Ahmad, S.; Salleh, A.B. Thermomyces lanuginosus lipase-catalyzed esterification of 9, 10-dihydroxystearic acid and monohydric alcohol. J. Oleo Sci. 2005, 54, 305-309. [CrossRef]

49. Romero, M.D.; Calvo, L.; Alba, C.; Daneshfar, A.; Ghaziaskar, H.S. Enzymatic synthesis of isoamyl acetate with immobilized Candida antarctica lipase in n-hexane. Enzym. Microb. Technol. 2005, 37, 42-48. [CrossRef]

50. Hari Krishna, S.; Divakar, S.; Prapulla, S.G.; Karanth, N.G.K. Enzymatic synthesis of isoamyl acetate using immobilized lipase from Rhizomucor miehei. J. Biotechnol. 2001, 87, 193-201. [CrossRef]

51. Kuo, C.-H.; Chiang, S.-H.; Ju, H.-Y.; Chen, Y.-M.; Liao, M.-Y.; Liu, Y.-C.; Shieh, C.-J. Enzymatic synthesis of rose aromatic ester (2-phenylethyl acetate) by lipase. J. Sci. Food Agric. 2012, 92, 2141-2147. [CrossRef]

52. He, W.S.; Li, J.J.; Pan, X.X.; Zhou, Y.; Jia, C.S.; Zhang, X.M.; Feng, B. Lipase-mediated synthesis of water-soluble plant stanol derivatives in tert-butanol. Bioresour. Technol. 2012, 114, 1-5. [CrossRef]

53. Wang, Y.; Zhang, D.H.; Chen, N.; Zhi, G.Y. Synthesis of benzyl cinnamate by enzymatic esterification of cinnamic acid. Bioresour. Technol. 2015, 198, 256-261. [CrossRef]

54. Yadav, G.D.; Devendran, S. Lipase catalyzed synthesis of cinnamyl acetate via transesterification in non-aqueous medium. Process Biochem. 2012, 47, 496-502. [CrossRef]

55. Lee, S.B.; Ryu, D.D.Y. External diffusion effects on the kinetic constants of immobilized enzyme systems. J. Theor. Biol. 1980, 84, 259-279. [CrossRef] [PubMed]

56. Kim, H.; Park, C. Enzymatic synthesis of phenethyl ester from phenethyl alcohol with acyl donors. Enzym. Microb. Technol. 2017, 100, 37-44. [CrossRef] [PubMed]

57. Romero, M.D.; Calvo, L.; Alba, C.; Daneshfar, A. A kinetic study of isoamyl acetate synthesis by immobilized lipase-catalyzed acetylation in n-hexane. J. Biotechnol. 2007, 127, 269-277. [CrossRef] [PubMed]

58. Danieli, B.; Luisetti, M.; Sampognaro, G.; Carrea, G.; Riva, S. Regioselective acylation of polyhydroxylated natural compounds catalyzed by Candida Antarctica lipase B (Novozym 435) in organic solvents. J. Mol. Catal. B Enzym. 1997, 3, 193-201. [CrossRef]

59. Chebil, L.; Anthoni, J.; Humeau, C.; Gerardin, C.; Engasser, J.M.; Ghoul, M. Enzymatic acylation of flavonoids: Effect of the nature of the substrate, origin of lipase, and operating conditions on conversion yield and regioselectivity. J. Agric. Food Chem. 2007, 55, 9496-9502. [CrossRef]

60. Stergiou, P.Y.; Foukis, A.; Filippou, M.; Koukouritaki, M.; Parapouli, M.; Theodorou, L.G.; Hatziloukas, E.; Afendra, A.; Pandey, A.; Papamichael, E.M. Advances in lipase-catalyzed esterification reactions. Biotechnol. Adv. 2013, 31, 1846-1859. [CrossRef]

61. Polynomials, R. Substrate inhibition and mixed dead-end and product inhibition. In Comprehensive Enzyme Kinetics; Springer: Boston, MA, USA, 2004; pp. 191-207. [CrossRef]

62. Chebil, L.; Humeau, C.; Falcimaigne, A.; Engasser, J.M.; Ghoul, M. Enzymatic acylation of flavonoids. Process Biochem. 2006, 41, 2237-2251. [CrossRef]

63. Yadav, G.D.; Dhoot, S.B. Immobilized lipase-catalysed synthesis of cinnamyl laurate in non-aqueous media. J. Mol. Catal. B Enzym. 2009, 57, 34-39. [CrossRef]

64. Khor, G.K.; Sim, J.H.; Kamaruddin, A.H.; Uzir, M.H. Thermodynamics and inhibition studies of lipozyme TL IM in biodiesel production via enzymatic transesterification. Bioresour. Technol. 2010, 101, 6558-6561. [CrossRef] 
65. Qian, J.; Gou, L.; Chen, Y.; Ding, J.; Xu, J.; Guo, H. Enzymatic acylation of flavone isolated from extractive of bamboo leaves with oleic acid and antioxidant activity of acylated product. Eng. Life Sci. 2019, 19, 66-72. [CrossRef]

66. Chang, S.W.; Shaw, J.F. Biocatalysis for the production of carbohydrate esters. New Biotechnol. 2009, 26, 109-116. [CrossRef] [PubMed]

67. Laane, C.; Boeren, S.; Vos, K.; Veeger, C. Rules for optimization of biocatalysis in organic solvents. Biotechnol. Bioeng. 1987, 30, 81-87. [CrossRef] [PubMed]

68. Milisavljevic, A.; Stojanovic, M.; Carevic, M.; Mihailovic, M.; Milosavic, N.; Bezbradica, D. Lipase-catalyzed esterification of phloridzin: Acyl donor effect on enzymatic affinity and antioxidant properties of esters. Ind. Eng. Chem. Res. 2014, 53, 16644-16651. [CrossRef]

69. Hazarika, S.; Goswami, P.; Dutta, N.N. Lipase catalysed transesterification of 2-o-benzylglycerol with vinyl acetate: Solvent effect. Chem. Eng. J. 2003, 94, 1-10. [CrossRef]

70. Mbatia, B.; Kaki, S.S.; Mattiasson, B.; Mulaa, F.; Adlercreutz, P. Enzymatic synthesis of lipophilic rutin and vanillyl esters from fish byproducts. J. Agric. Food Chem. 2011, 59, 7021-7027. [CrossRef]

71. Vaisali, C.; Belur, P.D.; Regupathi, I. Lipase mediated synthesis of rutin fatty ester: Study of its process parameters and solvent polarity. Food Chem. 2017, 232, 278-285. [CrossRef] 